\title{
SOME ECONOMIC CONSEQUENCES OF COMMODITY CONTROL
}

\author{
Cari L. Alsberg*
}

In appraising legislation intended to protect public health or prevent fraud, it is not enough to inquire whether the abuses aimed at are likely to be cured; political, economic, and social consequences need to be envisaged also. Only with due consideration of these should one venture to answer the question: Are the net consequences worth while? Clear thinking upon this question will probably become increasingly important, since control over commodities is likely to be extended merely to prevent fraud, even though no danger to the public health is involved. The purpose of this paper is to set forth a few of the factors that need to be kept in mind in answering the above question; limitations of space forbid exhaustive analysis.

Commodity-control legislation may handicap some of those who produce for export, if it causes higher production costs than in competing countries; but it may aid others by inspiring confidence in foreign countries in the quality of goods produced under control. Thus our Meat Inspection Act of $1906^{1}$ leads to the sale of some lard as white grease and consequently to higher costs, and this in turn to change in the price relationships of lard and white grease throughout the world. Hog prices are affected thereby and, indirectly, the prices of corn and of such lard substitutes as vegetable shortening, margarine, and cottonseed oil. On the other hand, the Meat Inspection Act aids exporters because it inspires confidence in American animal foods. Indeed, a law providing for the inspection of meats for export was enacted some years before the Meat Inspection Act, not so much in response to an insistent demand for protection of the public as to conserve our export trade, jeopardized by the food laws of foreign countries. If the United States was to retain its foreign markets, it was necessary to clean house at home.

Many American manufacturers of that day regarded European food laws as really camouflaged embargoes or tariffs. The Meat Inspection Act, the Food and Drugs Act (also passed in I906), ${ }^{2}$ and the Plant Quarantine $\mathrm{Act}^{3}$ have turned the tables on

- B.A., 1896, M.A., I900, Columbia University; M.D., College of Physicians and Surgeons, Columbia University, I900; Universities of Strassburg and Berlin, I900-1903. Chief of the Bureau of Chemistry, U. S. Department of Agriculture, 1912-I921. Director of Stanford Food Research Institute since 1921.

${ }_{34}$ STAT. 674, 2 I U. S. C. A., \$\$7T-95.

34 STAT. 768, 2 U. U. C. A., \$\$I-15.

37 Stat. 3 I6 (rgr2), 7 U. S. C. A., \$\$r5I-r65. 
them, and foreigners now make the same charge against the United States. Obviously, commodity-control laws contain the germ of not a little potential friction between nations; but they may also accentuate economic conflict at home-set the city against the country, the south against the north, the west against the east. Thus oleomargarine legislation has always been supported by the dairy farmers of the north and opposed by labor and also by the cotton farmers of the south who find an important outlet for cottonseed oil in margarine. Before the War, the food law sharpened the conflict between the grape growers of the east and those of California. Wine can be made from Califorinia grape juice without dilution, but in the east addition of water and sugar to the must may be necessary in bad years, if the wine is to be palatable. Because a ton of grapes then yields more wine, Californian vineyardists asked that food officials suppress the practice; an essentially economic sectional struggle became a matter for governmental intervention. Cases of this kind might easily! be multiplied.

A different kind of conflict inevitably arises if control is based on the interstatecommerce clause of the Constitution, because some zoning of markets results, which may give rise to considerable intersectional political friction. Meat packing is zoned in this way because the channels of interstate and foreign commerce are closed to establishments without federal inspection. Only plants of some size are federally inspected. Further zoning results from the existence of municipal inspection. Meat products may not everywhere move freely from the country districts into a city or from one city to another or out of the state into other states or into export. Those who are advantaged endeavor through political pressure to exploit the system as a sort of internal embargo. The smaller packers doing a local business unhampered by federal inspection may enjoy appreciable advantages over their larger federally-inspected competitors. They may purchase animals at a low price that would not pass federal inspection. Their capital investment may be small because they need not meet the requirements of the federal government in regard to sanitation and the like. In his local territory, the local butcher is, therefore, often able to compete successfully with the great packer. On the other hand, because he is limited to the local market, he may sometimes have to divert certain kinds of edible material to low-priced nonfood uses. The local consumer buys his meats at lower prices, but runs some risk of consuming meats from possibly-diseased animals. The local farmer gets a somewhat higher price for animals that might not pass federal inspection, and perhaps a somewhat higher price for those that would. There is less freighting of livestock and slaughterhouse products around the country. Centralization of the meat-packing industry tends to be prevented. Many small butchers continue to employ local labor, to pay local taxes, and to furnish a local market for livestock, but there are social wastes arising from the inability of small butchers to utilize by-products efficiently.

The Food and Drugs Act has not had as extensive zoning effects as the Meat Inspection Act, except upon the trade in market milk. The milk supply of a great 
city like New York has to come from a great distance. Market milk has been delivered on occasion to New York from as far away as Wisconsin, where the costs of milk production are lower than in New York State. The regulations for New York and other cities involve very definite requirements in regard to sanitation on the farm, and they are enforced by municipal inspection. No dairyman whose plant does not meet these requirements is permitted to send milk into New York City. Obviously, it is difficult for a dairyman in the middlewest to have his farm inspected in order that he may ship to New York. The New York milk regulations, therefore act like a tariff or embargo and result in zoning the dairy business. A dairy farmer wishing to sell milk in several different states may have to meet the requirements of several cities; and these may not be consistent with one another. There have been times when a New Jersey farmer, wishing to sell milk in Philadelphia, Newark, and New York, had to submit to three separate and distinct inspections. The economic effects upon the milk consumer, upon the dairyman, upon the distribution of dairying over the United States, and upon the freight business of the railroads are obvious. Charges have not been wanting that milk inspection has been so shaped as to serve the ends of a tariff between the states.

Food manufacturers in large cities have sometimes produced goods which are permitted to be sold within the city that could not be sold in interstate commerce. For example, in the city of New York, ice cream has at times been produced and sold which could not be drayed to Hoboken or Jersey City without violating the federal food law. A confectioner who sold a I5-ounce box of candy in his home city has been known to truck candy in bulk to a branch house across a state line and there to pack in I5-ounce boxes, thus avoiding the necessity of complying with the net-weight provision of the federal food law and informing purchasers that his boxes did not contain a full pound of candy. The writer has known of cases in which food manufacturers have produced goods that were adulterated under the federal law or of very low quality to sell in their own city or state and a quite different, superior line for sale outside their state. There have also been instances in which local requirements were allegedly superior to the federal requirements, as, for example, formerly in New York City where skim milk could not be sold legally, whereas it could be shipped legally in interstate commerce if not misrepresented. The law may thus confer a competitive advantage on the small concern which need not comply with the federal law, because it does not do an interstate business. It has happened, though rarely, that such a concern, as it grew, found it advantageous to evade the federal law by establishing a branch factory in another state rather than to enlarge its existing capacity and ship in interstate commerce.

Obviously, commodity-control legislation may present all the economic effects of tariffs. While tariffs were low, the Meat Inspection Act restricted the importation of Fresh, chilled, and frozen meat. Prices of meats in all importing and exporting countries unquestionably were, and perhaps still are, influenced thereby. To size up all 
the consequences, it would be necessary to evaluate the losses to producers and gains to consumers in all foreign countries, as well as the benefits to American producers. It would be necessary also to balance the losses from higher prices to American consumers against the quite imponderable, though very real value of protection against meats prepared possibly under insanitary conditions. Perhaps the disadvantages to producers outside the United States are greater than the gains to the United States. Foreigners might be led to retaliate, and perhaps do, by buying less in the United States. This must ultimately follow in any event, because the foreigner can buy in the long run only if he is permitted to offer something in exchange. Foreign governments, even, may retaliate by tariffs, quotas, embargoes, and other restrictive measures aimed at American goods. In the United States, all producers for export are affected in proportion. Moreover, ill will may be generated with appreciable repercussions not merely upon American export trade but also upon tourist travel. In the case of the Meat Inspection Act, one can justify restriction of imports on the ground of public-health protection. In the case of other commodities not affected with a publichealth interest, justification is sometimes more difficult.

The Tea Importation Act of $1897^{4}$ is a case in point. It contains among other provisions a prohibition of the importation of tea below a certain quality. ${ }^{5}$ The effect has been to limit importations from countries producing the lowest grades, and to weaken to some extent the power of these countries to buy from the United States. Importation from other countries has been favored and their capacity to buy American goods increased. The geographical distribution of tea culture has possibly been changed and price differentials between low and high grades widened. Since only the better grades are permitted entry into the United States, the average American price has probably been higher than it would otherwise have been. Per capita consumption in the United States may have been raised because no tea has been admitted so poor as to disgust users with tea drinking, but at the same time high prices may have restricted the market. Some of the very poor may have purchased less than otherwise they would have elected to buy. There may be consumer classes who prefer low quality at a low price to higher quality at a higher price because they are undiscriminating. On the other hand, those who are able to pay for average, or better than average, grades have had no very poor teas palmed off on them. Such considerations as these raise the question whether the best interests of consumers as a whole might not have been served better by a law which, in addition to preventing the adulteration which the present law prohibits, compelled adequate truthful branding instead of forbidding importation of low-grade teas.

Most people are apt to assume that the purpose of commodity legislation is to ensure them goods of high quality. However, a law accomplishing more than to ensure the consumer his money's worth is of questionable value. Quality is a relative, often a purely subjective, concept, for scarcity and esthetic considerations often de-

\footnotetext{
- 29 STAT. 604, 2 I U. S. C. A., $\$ \$ 41-50$.

'Such teas are admittedly neither more nor less wholesome than the better grades.
} 
termine itg. High quality has to be paid for. The cost of living would be raised enormously, if there were none but high-quality goods on the market. Indeed, in many commodity classes, there might not be enough to go around-canned peaches, for example, in which the difference between the very highest grade and the grades immediately below is not one of good value or flavor, but of appearance merely. It must be remembered that most of us buy with our eyes.

The cost of doing business may rise, even for the honest man, because of control legislation. Special forms of labeling and packaging may be required, or the keeping of books in a definite way, or manufacturing may have to be done under specified sanitary conditions, or chemists and other technologists may have to be employed, etc., etc. It is of no moment to business men if costs go up alike for all of them, since added costs are usually passed on to the consumer. Unfortunately, these costs are apt to weigh more heavily upon the small than upon the large business, for more capital may be required which the large concern can usually secure more easily than the small one. For a small business, the employment of technologists and the maintenance of testing laboratories may prove difficult, because it may increase fixed charges more than the volume of business permits. On the other hand, many manufacturers would be saved the cost of testing deliveries in the laboratory. The expenditure in labor and materials that would be unnecessary for this purpose, if falsification were punishable, it is impossible to estimate, but it would probably be very large indeed. Not the least gain would be social, for a vast improvement of business morals would result with repercussions on society as a. whole that no one could appraise. The business man is often compelled to adulterate or be ruined. It may be true that honesty is the best policy in the long run, but many a manufacturer has not the resources to last for even a not-very-long long run. The effects of this kind of unfair competition on business ethics and upon the tone of the commercial world are undoubtedly profound and evil.

It is a fallacy to argue that, when the debasement of a commodity has become general, it is never of import to the public welfare, since demand and supply determine the price. Weighting of sole leather, for example, adds nothing to its wearing quality; it may give a false appearance and feel of firmness to inferior leather. Since it takes as much labor and nearly as much capital to produce shoes with inferior weighted soles as with superior ones, more capital and more labor are needed to keep a person in footgear for a given time if he wears inferior shoes than if he wears better ones. As an individual he may not be disadvantaged, if he has paid a low price for the inferior shoes that soon wear out, but there is social waste of capital and labor nevertheless, to say nothing of the waste of loading material (glucose and epsom salts) and the unnecessary manufacturing expense of weighting. In general, if costs of raw materials are small as compared with costs of labor and distribution, the production of low-grade goods is not in the national interest. On the other hand, if the low-quality goods are also serviceable and cheap, they become attainable for 
larger classes whose standard of living may in consequence rise. The increase in demand may then make mass production possible, which in turn may more than wipe out the wastes of labor and capital resulting from the manufacture of the poorer product. The net result may well mean material social gains.

With increasing mechanization of industry, this has been the course of events in the modern world and especially in America. Labor is tending more and more to represent a smaller and smaller element in the costs of production. In consequence, cheap goods with a short life become better buys, especially goods subject to changes in style. The extreme case is the wood-pulp plate used for a single picnic meal, or the paper towel which, though used only once, is economical because the costs of laundering are saved. Such goods are typical of American economic life, and with them the tremendous development of junking in the United States. In the old world, goods are still expected to last, if possible, forever. Obviously, one cannot generalize about commodities as a whole. Each class of commodities has to be considered as a special case. Thus the question is more important for durable than for non-durable goods. General lowering of quality in merchandize, though accompanied by a lowering in price, is a matter of public concern as a question of national policy. It may well be that some check in the way of commodity-control legislation is in the public interest.

Social gains of this sort involve more or less change in manufacturing processes, but government control tends inevitably to crystallize and fossilize trade practices. The manufacturer, in considering whether or not it is wise for him to take up the production of a new product, especially if it is a substitute or imitation, must base his decision not merely upon his judgment of the probability of earning profits but also upon the probable attitude of law-enforcing officials regarding branding and other conditions of marketing. The protection of the public from frauds of necessity entails some discouragement of the introduction of new products, even though they be meritorious, and also some delay in the application of science and invention to industry.

It must be clear to the reader by this time that far-reaching political, economic, and social consequences may follow in the wake of commodity-control legislation, and that benefits cannot be weighed against disadvantages in any scientific manner, since neither the benefits nor the advantages can be measured in terms of social welfare. Each type and class of commodity presents its own problems. Each person must weigh benefits and disadvantages on the scale of his own social and political philosophy. There is probably only one point of view on which all would agree: it is that the public health must be protected, even at very high cost. To attempt to balance benefits to public health against economic or other social costs is to compare incommensurables. All that can be done is to recognize the existence of these costs and to reduce them to whatever extent is compatible with public health. When health is not involved, the striking of a balance in rather general terms is not impossible. It is in this unsatisfactory state that we must leave our subject. 